\title{
GAME PUZZLE BERBASIS FUZZY C-MEAN UNTUK MEMETAKAN SOAL UJIAN NASIONAL FISIKA SMA
}

\author{
Oleh: Lukita Yuniati *), Abdul Syukur *), dan Romi Satria Wahono **)
}

\section{Abstrak}

Hasil Ujian Nasional Fisika SMA Tahun 2007-2008 yang dilaporkan Badan Standar Nasional Pendidikan (BSNP) sebagai penyelenggara Ujian Nasional rendah. Faktor-faktor yang mempengaruhinya adalah alokasi yang disediakan untuk menyampaikan materi Ujian Nasional Fisika terbatas, materi soal Ujian Nasional Fisika banyak dan siswa kurang latihan soal Ujian Nasional fisika padahal dril soal Ujian Nasional Fisika sangat perlu untuk persiapan Ujian Nasional Fisika SMA. Agar kegiatan drill soal yang diberikan siswa mendapatkan hasil yang maksimal, guru harus pandai memetakan soal yang akurat. Berdasarkan angket yang disebarkan kepada 50 orang guru Fisika Kota Semarang bahwa guru sulit memetakan soal Ujian Nasional Fisika SMA. Dan berdasarkan angket 120 siswa SMA N 7 Semarang diketahui bahwa dril soal dalam mempersiapkan Ujian Nasional Fisika SMA adalah kegiatan yang membosankan dan tidak menantang. Untuk memudahkan guru memetakan soal Ujian Nasional Fisika pada penelitian ini digunakan fuzzy c-mean. Untuk memetakan soal Ujian Nasional Fisika kegiatan yang mulamula harus dilakukan adalah kegiatan mengelompokkan soal Ujian Nasional Fisika dalam clustercluster tertentu. Metode clustering yang digunakan berbasis fuzzy c-means. Fuzzy c-means adalah suatu teknik pengklasteran fuzzy dimana keberadaan tiap-tiap titik data dalam suatu klaster ditentukan oleh derajat keanggotaan. Proses clustering berbasis fuzzy c-means menunjukkan hasil yang lebih baik dan lebih alami dibandingkan dengan proses kluster dengan pendekatan tegas. Hasil clustering soal Ujian Nasional Fisika SMA berbasis fuzzy c-mean dijadikan dasar pembuatan game puzzle untuk kegiatan dril soal Ujian Nasional Fisika dalam rangka untuk mempersiapkan siswa kelas XII IA dalam menghadapi Ujian Nasional Fisika SMA.

Kata kunci: Ujian Nasional, fuzzy c-mean, game puzzle

\section{A. LATAR BELAKANG}

Hasil Ujian Nasional Fisika SMA Tahun 20072008 yang dilaporkan Badan Standar Nasional Pendidikan (BSNP) sebagai penyelenggara Ujian Nasional rendah. Prosentase ketuntasan yang dicapai siswa baik tingkat sekolah, kota, propinsi maupun
Nasional berturut-turut $65.90 \%, 67.80 \%$, $71.70 \%$ dan $69.10 \%$. Nilai prosentase penguasaan materi ini masih jauh dari Kriteria Ketuntasan Minimal (KKM) yang ditentukan Pemerintah yaitu $75 \%$. Di bawah ini merupakan laporan Badan Standar Nasional Pendidikan pada Ujian Nasional Fisika SMA Tahun 2007-2008.

*) Dra. Lukita Yuniati, M. Kom., guru Fisika SMA N 7 Semarang, meneruskan S2 pada Magister Teknik Informatika Konsentrasi Game Technology Pasca Sarjana Universitas Dian Nuswantoro

*) Dr. Abdul Syukur, Direktur Pasca Sarjana Universitas Dian Nuswantoro

***) Romi Satria Wahono, M. Eng., dosen Magister Teknik Informatika Dian Nuswantoro, Pendiri dan Koordinator Ilmu Komputer.Com., dan pemerhati masalah game technology 
Untuk mengetahui lebih dalam faktor apa saja yang mempengaruhi rata-rata penguasaan materi Ujian Nasional rendah maka disebarkan angket tentang upaya peningkatan hasil Ujian Nasional Fisika dan 50 orang guru Kota Semarang dan 120 siswa SMAN 7 Semarang. Hal ini terangkum pada tabel berikut:

Tabel 1.

Hasil Angket Guru tentang Pemetaan Soal Ujian Nasional Fisika SMA

\begin{tabular}{|l|c|}
\hline \multicolumn{1}{|c|}{ Materi yang ditanyakan } & Prosentase \\
\hline Pemetaan soal Ujian Nasional sangat perlu & $86 \%$ \\
\hline Guru mersa sulit melakukan pemetaan soal Ujian Nasional & $80 \%$ \\
\hline Pemetaan soal Ujian Nasional masih dilakukan manual & $100 \%$ \\
\hline Pemetaan soal Ujian Nasional belum diprogram dengan bantuan komputer & $100 \%$ \\
\hline
\end{tabular}

Tabel 2.

Angket Siswa Tentang Persiapan Menghadapi Ujian Nasional Fisika

\begin{tabular}{|l|c|}
\hline \multicolumn{1}{|c|}{ Materi Yang Ditanyakan } & Prosentase \\
\hline Dril soal membosankan dan tidak menantang & $74.17 \%$ \\
\hline Pemanfaatan game dalam pembelajaran adalah kegiatan bagus & $92.67 \%$ \\
\hline Siswa senang game & $76.67 \%$ \\
\hline
\end{tabular}

\section{B. RUMUSAN MASALAH}

Berdasarkan paparan pada latar belakang, perumusan pada penelitian ini adalah:

1. Kesulitan memetakan dan mendesain evaluasi dengan tingkat kesulitan yang proposional.

2. Dril soal dalam mempersiapkan UN Fisika SMA adalah kegiatan yang membosankan dan tidak menantang.

\section{TUJUAN}

Dari perumusan masalah penelitian di atas maka tujuan penelitian ini adalah:

1. Terciptanya model pemetaan soal Ujian Nasional Fisika SMA dengan metode Fuzzy C-Mean untuk memudahkan proses desain evaluasi dalam Ujian Nasional dengan sebaran tingkat kesulitan yang proporsional.

2. Tersedianya latihan soal yang menyenangkan dan menantang dengan menggunakan game puzzle guna mempersiapkan siswa dalam Ujian Nasional Fisika SMA.

\section{MANFAAT}

Adapun penelitian ini dapat memberikan beberapa manfaat antara lain sebagai berikut:

1. Manfaat praktis hasil penelitian ini diharapkan dapat digunakan Kemendiknas mendesain evaluasi dengan sebaran tingkat kesulitan yang proposional.

2. Manfaat teoritis, hasil penelitian ini diharapkan dapat memberikan sumbangan untuk pengembangan teori belajar, strategi dan model belajar yang digunakan guru dalam mempersiapkan siswa menghadapi UN Fisika SMA

3. Manfaat kebijakan, hasil penelitian ini diharapkan dapat memberikan masukan dan sumbangan pada pemerintah atau pihak-pihak yang berkepentingan dalam rangka mengambil kebijakan yang berkaitan dengan sistem pelaksanaan Ujian Nasional.

4. Sebagai acuan bagi peneliti selanjutnya, khususnya penelitian yang berkaitan dengan pengembangan kegiatan clustering berbasis fuzzy c-mean. 


\section{E. LANDASAN TEORI}

\section{Fuzzy C-Mean}

Fuzzy C-means (FCM), atau dikenal juga sebagai Fuzzy ISODATA, merupakan salah satu metode mapping maupun clustering yang merupakan bagian dari metode Hard K-Means. FCM menggunakan model pengelompokan fuzzy sehingga data dapat menjadi anggota dari semua kelas atau cluster terbentuk dengan derajat atau tingkat keanggotaan yang berbeda antara 0 hingga 1.

Tingkat keberadaan data dalam suatu kelas atau cluster ditentukan oleh derajat keanggotaannya. Teknik ini pertama kali diperkenalkan oleh Jim Bezdek pada tahun 1981. Konsep dasar FCM, pertama kali adalah menentukan pusat cluster yang akan menandai lokasi ratarata untuk tiap-tiap cluster. Pada kondisi awal, pusat cluster ini masih belum akurat. Tiap-tiap data memiliki derajat keanggotaan untuk tiap-tiap cluster. Dengan cara memperbaiki pusat cluster dan nilai keanggotaan tiap-tiap data secara berulang, maka dapat dilihat bahwa pusat cluster akan menujui lokasi yang tepat. Perulangan ini didasarkan pada minimasi fungsi obyektif (Gelley, 2000).

\section{Game Puzzle}

Game puzzle disebut juga game teka-teki. Game puzzle lebih cenderung mencari jalan keluar melalui jalan-jalan yang berlika-liku dan membingungkan. (Pedersen, 2003). Game Puzzle tidak mudah dilupakan karena pemain game mendapati kesulitan sehingga pemain mendapat pengalaman yang sangat mengesankan.(Tom Meigs,2003).

\section{Ujian Nasional}

a. Penyelenggara Ujian Nasional adalah Badan Standar Nasional Pendidikan (BSNP).

b. Tujuan Ujian Nasional

1) Pemetaan mutu satuan dan/atau program pendidikan

2) Dasar seleksi masuk jenjang pendidikan berikutnya

3) Penentuan kelulusan peserta didik dari program dan/atau satuan pendidikan

4) Pembinaan dan pemberian bantuan kepada satuan pendidikan dalam upaya peningkatan mutu pendidikan

c. Pemetaan Soal Ujian Nasional Fisika Menurut matematika bahwa suatu pemetaan/fungsi dari himpunan A ke himpunan $B$ adalah suatu relasi khusus sedemikian rupa sehingga, setiap anggota A dipasangkan dengan tepat satu anggota $B$. ditulis $f$ $: A \rightarrow B$. Himpunan A disebut domain fungsi, dan himpunan $B$ disebut codomain fungsi.

Pemetaan soal UN adalah kegiatan mengidentifikasi penyebaran soal Ujian Nasional berdasarkan Standar Kompetensi Lulusan (SKL), materi dan kemampuan yang diuji. Untuk mempersiapkan siswa menghadapi UN salah satu metode yang efektif dengan cara drilling. Pemetaan soal UN bertujuan agar dril soal yang diberikan kepada siswa memiliki keakuratan yang tinggi.

\section{Teori Hukum Latihan (Law of Exercise)}

Hukum Latihan (law of exercise), yaitu semakin sering tingkah laku diulang/ dilatih (digunakan), maka asosiasi tersebut akan semakin kuat. Prinsip law of exercise adalah koneksi antara kondisi (yang merupakan perangsang) dengan tindakan akan menjadi lebih kuat karena latihan-latihan, tetapi akan melemah bila koneksi antara keduanya tidak dilanjutkan atau dihentikan. Prinsip menunjukkan bahwa prinsip utama dalam belajar adalah ulangan. Makin sering diulangi, materi pelajaran akan semakin dikuasai.

\section{F. KERANGKA PEMIKIRAN}

Paparan di atas dapat digambarkan pada gambar berikut ini. 


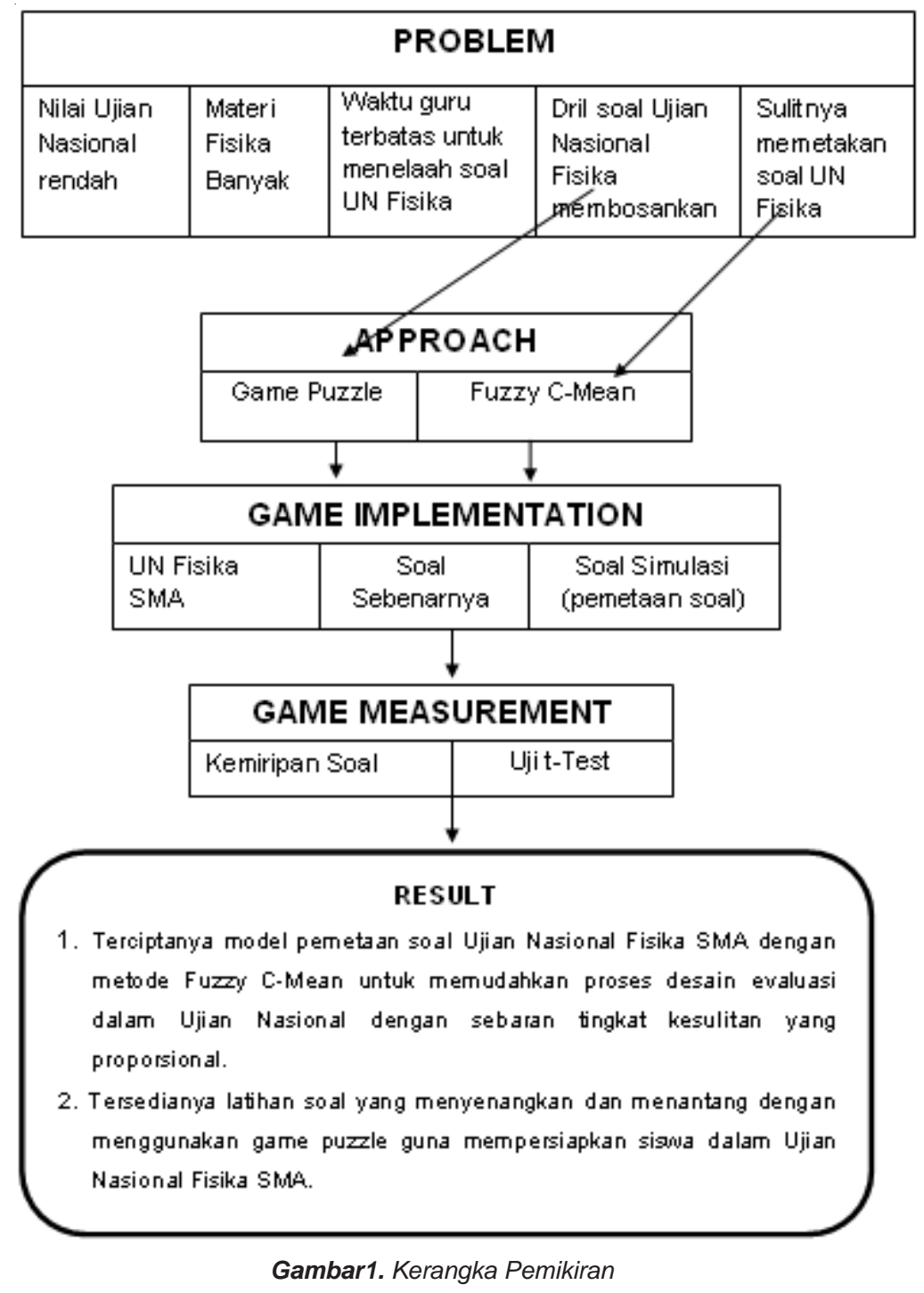

\section{G. METODOLOGI PENELITIAN}

\section{Perancangan Penelitian}

a. Jenis Penelitian

Penelitian ini merupakan penelitian eksperimen. Data eksperimen diambil dari laporan Badan Standar Nasional Pendidikan tentang penguasaan materi Ujian Nasional Tahun 20082009 tentang prosentase penguasaan materi Ujian Nasional Fisika SMA.

b. Metode Pengumpulan Data Laporan Badan Standar Nasional Pendidikan yang berisi penguasaan materi Ujian Nasional Fisika SMA meliputi tingkat SMA N 7 Semarang, Kota Semarang, Jawa Tengah dan Nasional.Dari data tersebut dianalisis dengan metode fuzzy c-mean. Ada 3 tahapan yang digunakan dalam metoda fuzzy c-mean antara lain: fuzzification, rule evaluation dan defuzzification.

c. Metode Pengukuran

Untuk mengukur tingkat keberhasilan bahwa fuzzy c-mean dapat memetakan soal UN Fisika SMA adalah dengan melihat nilai yang dicapai pada kelompok kontrol kelompok treatment. Nilai pada kedua kelompok kemudian dibandingkan dengan uji t-Test. 


\section{Penerapan Fuzzy C-Mean Untuk Memetakan Soal Ujian Nasional Fisika SMA}

Pada fuzzy system terdapat tiga proses yaitu:

\section{a. Fuzzification}

Pada logika Fuzzy, fuzzification adalah masukan-masukan yang nilai kebenarannya bersifat pasti (crisp input) dikonversi ke bentuk fuzzy input. Pada penelitian ini proses fuzzification yaitu dengan menelaah Iaporan Badan Standar Nasional Pendidikan (BSNP) tentang prosentase penguasaan materi Ujian Nasional Fisika SMA.

b. Rule Evaluation

Rule Evaluation adalah proses untuk mencari suatu nilai fuzzy output dari fuzzy input. Dari data input yaitu laporan dari Badan Standar Nasional Pendidikan tentang penguasaan materi Ujian Nasional Fisika dapat diketahui prosentase ketuntasan yang dicapai siswa pada tiap materi. Dari data tersebut maka materi soal Ujian Nasional dikelompokkan dalam 3 cluster yaitu soal mudah untuk cluster 3 , sedang untuk cluster 2 dan sulit untuk cluster1.

1). Frekuensi untuk memperbaiki tiap cluster

$$
\begin{aligned}
& \text { Iteration count }=1, \text { obj. } f c n=28198.548324 \\
& \text { Iteration count }=2, \text { obj. } f c n=19863.4388881
\end{aligned}
$$

Fungsi fcm secara iterative memperbarui pusat-pusat cluster dan derajad keanggotaan tiap titik data sampai sedekat mungkin dengan pusat cluster yang "benar". Fungsi yang dipakai untuk menentukan seberapa dekat jarak pusat cluster terhadap posisi yang "benar" adalah jarak suatu titik dengan pusat cluster dikalikan dengan derajat keanggotaan titik data terhadap cluster tersebut. Dari data di atas dapat diartikan bahwa perbaikan anggota cluster dilakukan 2 kali dengan rincian perbaikan 1 dilakukan sampai $28.198,548324$ kali dan perbaikan 2 sampai $19.863,438888$ kali sehingga jarak anggota cluster paling minimum dengan jarak pusat cluster.

2) Pusat Cluster Laporan Badan Standar Nasional Pendidikan Nasional (BSNP) tentang prosentase penguasaan materi Ujian Nasional Fisika SMA meliputi prosentase UN Fisika SMA yang dicapai siswa SMA tingkat sekolah, kota, propinsi dan Nasional. Dengan program MATLAB 7.1 dapat secara otomatis mencari pusat cluster prosentase materi Ujian Nasional Fisika SMA.

Tabel 3. Pusat Cluster 1,2 dan 3

\begin{tabular}{|l|c|c|c|c|}
\hline Cluster & $\begin{array}{c}\text { SMA N 7 } \\
\text { Sng }\end{array}$ & Semarang & Jawa Tengah & Nasional \\
\hline Cluster 1 & 40.6340 & $45.169 ;$ & 52.3103 & 62.5230 \\
\hline Cluster 2 & 66.0168 & $66.33 \div 3$ & 70.5409 & 69.2253 \\
\hline Cluster 3 & 63.4956 & 64.1068 & 68.3633 & 66.3585 \\
\hline
\end{tabular}

Dari data di atas menunjukkan bahwa nilai-nilai tersebut merupakan "koordinat" titik pusat ketiga cluster dan memberikan garis besar citra tiap cluster. Tiap cluster beranggotakan daya serap nilai Ujian Nasional Fisika tingkat SMAN7 Smg, Semarang, Jawa Tengah dan Nasional.

a) Untuk cluster-1, "koordinat" dari titik pusat cluster ini adalah:

$\left[\begin{array}{llll}\mathrm{v} 1.1 & \mathrm{v} 1.2 & \mathrm{v} 1.3 & \mathrm{v} 1.4\end{array}\right]=$ $\left[\begin{array}{lll}40.6340 & 47.1697 & 52.3103\end{array}\right.$ 62.5220]

Arti fisisnya, koordinat titik pusat cluster 1 daya serap nilai Ujian Nasional Fisika tingkat SMAN7 Smg, Semarang, Jawa Tengah dan 
Nasional adalah berturut-turut adalah 40.6340; 47.1697; 52.3103; 62.5220.

b) Untuk cluster-2, "koordinat" dari titik pusat cluster ini adalah:

$\left[\begin{array}{llll}\mathrm{v} 2.1 & \mathrm{v} 2.2 & \mathrm{v} 2.3 & \mathrm{v} 2.4\end{array}\right]=$ $\left[\begin{array}{lll}66.0168 & 66.3373 & 70.5409\end{array}\right.$ 69.2253]

Arti fisisnya, koordinat titik pusat cluster 2 daya serap nilai Ujian Nasional Fisika tingkat SMAN7 Smg, Semarang, Jawa Tengah dan Nasional adalah berturut-turut adalah 66.0168; 66.3373; 70.5409; 69.2253.

c) Untuk cluster-3, "koordinat" dari titik pusat cluster ini adalah:

$\left[\begin{array}{llll}\mathrm{v} 3.1 & \mathrm{v} 3.2 & \mathrm{v} 3.3 & \mathrm{v} 3.4\end{array}\right]=$ $\left[\begin{array}{lll}63.4956 & 64.1068 & 68.3633\end{array}\right.$ 66.3585]

Arti fisisnya, koordinat titik pusat cluster 3 daya serap nilai Ujian Nasional Fisika tingkat SMAN7 Smg, Semarang, Jawa Tengah dan Nasional adalah berturut-turut adalah 63.4956; 64.1068; $68.3633 ; 66.3585$.

3) Derajat Keanggotaan Tiap Soal Pada Semua Cluster

Pada penelitian ini data dikelompokkan dalam 3 cluster yaitu sukar, sedang dan mudah. Setiap soal akan menjadi anggota cluster tersebut jika nilai derajad keanggotaannya paling besar dibandingkan dengan derajad keanggotaan cluster yang lain.

c. Deffuzification

Defuzification adalah proses untuk menentukan suatu nilai crisp output. Derajat keanggotaan pada tiap cluster tiap soal dapat menentukan tingkat kesulitan soal dan level gamenya. Hubungan cluster, tingkat kesulitan soal dan level game adalah sebagai berikut:
Tabel 4.

Hubungan Cluster, Tingkat Kesulitan dan Level Game

\begin{tabular}{|c|c|c|c|}
\hline No & Chuster & $\begin{array}{c}\text { Tingkat } \\
\text { Kesulitan Soal }\end{array}$ & $\begin{array}{c}\text { Level } \\
\text { Game }\end{array}$ \\
\hline 1 & Cluster 1 & Sulit & 3 \\
\hline 2 & Cluster 2 & Sedang & 2 \\
\hline 3 & Cluster 3 & Mudah & 1 \\
\hline
\end{tabular}

Pada penelitian ini cluster 1 adalah kelompok soal sukar dan termasuk level 3 pada game, cluster 2 adalah kelompok soal sedang dan termasuk level 2 pada game dan cluster 3 adalah kelompok soal mudah dan termasuk level 1 pada game.

Dengan program MATLAB 7.1 dapat secara otomatis ditentukan derajad keaanggotaan semua cluster pada setiap soal Ujian Nasional Fisika SMA. Setiap soal akan menjadi anggota cluster tersebut jika nilai derajad keanggotaannya paling besar dibandingkan dengan derajad keanggotaan cluster yang lain.

Dari paparan di atas maka penerapan Fuzzy C-Mean untuk memetakan Soal Ujian Nasional Fisika dapat digambarkan pada gambar berikut ini:

Dari grafik di atas dapat dilihat, derajad keanggotaan tiap cluster tiap nomor soal Ujian Nasional Fisika SMA disajikan dalam satu garis vertikal dengan warna yang berbeda. Warna biru menggambar derajad keanggotaan cluster 1 , warna hijau menggambarkan derajad keanggotaan cluster 2 dan warna merah menggambarkan derajad keanggotaan cluster 3 .

\section{H. HASIL DAN PEMBAHASAN}

Berdasarkan i hasil clustering dengan metoda fuzzy c-mean kemudian dibuat game puzzle untuk kegiatan dril soal UN Fisika yang digunakan siswa kelas XII IImu Alam untuk 
Tabel 5. Penentuan Cluster Berdasarkan Derajat keanggotaan

\begin{tabular}{|c|c|c|c|c|c|c|}
\hline No & $\begin{array}{c}\text { Materi UN Fis } \\
\text { SMA }\end{array}$ & $\begin{array}{c}\text { Cluster } \\
1\end{array}$ & $\begin{array}{c}\text { Cluster } \\
2\end{array}$ & $\begin{array}{c}\text { Cluster } \\
3\end{array}$ & $\begin{array}{c}\text { Masukke } \\
\text { Cluster }\end{array}$ & $\begin{array}{c}\text { Tingkat } \\
\text { Kesulitan Soal }\end{array}$ \\
\hline 1 & $\begin{array}{l}\text { Kapasitor keping } \\
\text { sejajar }\end{array}$ & 0.5417 & 0.2177 & 0.2406 & Cluster 1 & sukar \\
\hline 2 & Gerak Lurus & 0.6410 & 0.1692 & 0.1898 & Cluster 1 & sukar \\
\hline 3 & $\begin{array}{l}\text { Gelombang } \\
\text { Berjalan }\end{array}$ & 0.6906 & 0.1441 & 0.1653 & Cluster 1 & sukar \\
\hline 4 & Alat optic & 0.6688 & 0.1550 & 0.1762 & Cluster 1 & sukar \\
\hline 5 & Hukum Kirchoff II & 0.6201 & 0.1783 & 0.2016 & Cluster 1 & sukar \\
\hline 6 & Gaya Magnetik & 0.6877 & 0.1430 & 0.1693 & Cluster 1 & sukar \\
\hline 7 & Induksi Magnetik & 0.7831 & 0.1001 & 0.1167 & Cluster 1 & sukar \\
\hline 8 & Induksi Faraday & 0.7863 & 0.0985 & 0.1152 & Cluster 1 & sukar \\
\hline 9 & Vektor & 0.7863 & 0.0988 & 0.1150 & Cluster 1 & sukar \\
\hline 10 & Impuls momentum & 0.8894 & 0.0496 & 0.0610 & Cluster 1 & sukar \\
\hline 11 & Teori atom & 0.3251 & 0.3133 & 0.3616 & Cluster 3 & mudah \\
\hline 12 & Usaha dan energy & 0.8449 & 0.0709 & 0.0842 & Cluster 1 & sukar \\
\hline 13 & Fluida statis & 0.6700 & 0.1541 & 0.1758 & Cluster 1 & sukar \\
\hline 14 & Radiasi & 0.8451 & 0.0677 & 0.0872 & Cluster 1 & sukar \\
\hline 15 & Titik berat & 0.6906 & 0.1427 & 0.1666 & Cluster 1 & sukar \\
\hline 16 & $\begin{array}{c}\text { Rangkaian arus } \\
\text { bolak-balik }\end{array}$ & 0.9175 & 0.0353 & 0.0472 & Cluster 1 & sukar \\
\hline 17 & Azas Black & 0.6099 & 0.1720 & 0.2180 & Cluster 1 & sukar \\
\hline 18 & Gaya elektrostatis & 0.7594 & 0.1028 & 0.1379 & Cluster 1 & sukar \\
\hline 19 & Gerak lurus & 0.2591 & 0.2789 & 0.4621 & Cluster 3 & mudah \\
\hline 20 & Taraf intensitas & 0.0666 & 0.5183 & 0.4152 & Cluster 2 & sedang \\
\hline 21 & Dinamika rotasi & 0.1056 & 0.3734 & 0.5211 & Cluster 3 & mudah \\
\hline 22 & Energi kinetikgas & 0.0389 & 0.3484 & 0.6128 & Cluster 3 & mudah \\
\hline 23 & Gerak parabola & 0.0277 & 0.2455 & 0.7268 & Cluster 3 & mudah \\
\hline 24 & Radioaktivitas & 0.0198 & 0.6732 & 0.3070 & Cluster 2 & sedang \\
\hline 25 & Hukum Newton & 0.0692 & 0.5417 & 0.3891 & Cluster 2 & sedang \\
\hline 26 & Themodinamika & 0.1051 & 0.5135 & 0.3814 & Cluster 2 & sedang \\
\hline 27 & Gaya gravitasi & 0.0577 & 0.5384 & 0.4039 & Cluster 2 & sedang \\
\hline 28 & Teori relativitas & 0.0773 & 0.5559 & 0.3668 & Cluster 2 & sedang \\
\hline 29 & $\begin{array}{l}\text { Pengukuran dan } \\
\text { angka penting }\end{array}$ & 0.1043 & 0.5187 & 0.3770 & Cluster 2 & sedang \\
\hline 30 & Interferensi difraksi & 0.0768 & 0.5419 & 0.3813 & Cluster 2 & sedang \\
\hline
\end{tabular}




\begin{tabular}{|c|c|c|c|c|c|c|}
\hline 31 & $\begin{array}{c}\text { Pengukuran dan } \\
\text { angka penting }\end{array}$ & 0.0773 & 0.5223 & 0.4004 & Cluster 2 & sedang \\
\hline 32 & Azas Black & 0.0654 & 0.5444 & 0.3902 & Cluster 2 & sedang \\
\hline 33 & Inti Atom & 0.0662 & 0.5454 & 0.3885 & Cluster 2 & sedang \\
\hline 34 & Arus listrik & 0.0829 & 0.5242 & 0.3929 & Cluster 2 & sedang \\
\hline 35 & Elastisitas & 0.1185 & 0.4860 & 0.3956 & Cluster 2 & sedang \\
\hline 36 & Azas Bemoulli & 0.0976 & 0.5151 & 0.3873 & Cluster 2 & sedang \\
\hline 37 & $\begin{array}{c}\text { Gelombang } \\
\text { elektromagnetik }\end{array}$ & 0.1286 & 0.4862 & 0.3852 & Cluster 2 & sedang \\
\hline 38 & Gerakmelingkar & 0.1371 & 0.4730 & 0.3899 & Cluster 2 & Sedang \\
\hline 39 & Efek Doppler & 0.1488 & 0.4631 & 0.3881 & Cluster 2 & Sedang \\
\hline 40 & Radiasi & 0.1425 & 0.4705 & 0.3871 & Cluster 2 & Sedang \\
\hline & & 0.1185 & 0.2893 & 0.5922 & Cluster 3 & Mudah \\
\hline
\end{tabular}

mempersiapkan Ujian Nasional. Semakin jitu memetakan soal Ujian Nasional Fisika berdasarkan Standar Kompetensi Lulusan maka diharapkan nilai yang dicapai siswa semakin bagus.

\section{Penerapan Fuzzy C-Mean Memetakan Soal Ujian Nasional Fisika SMA}

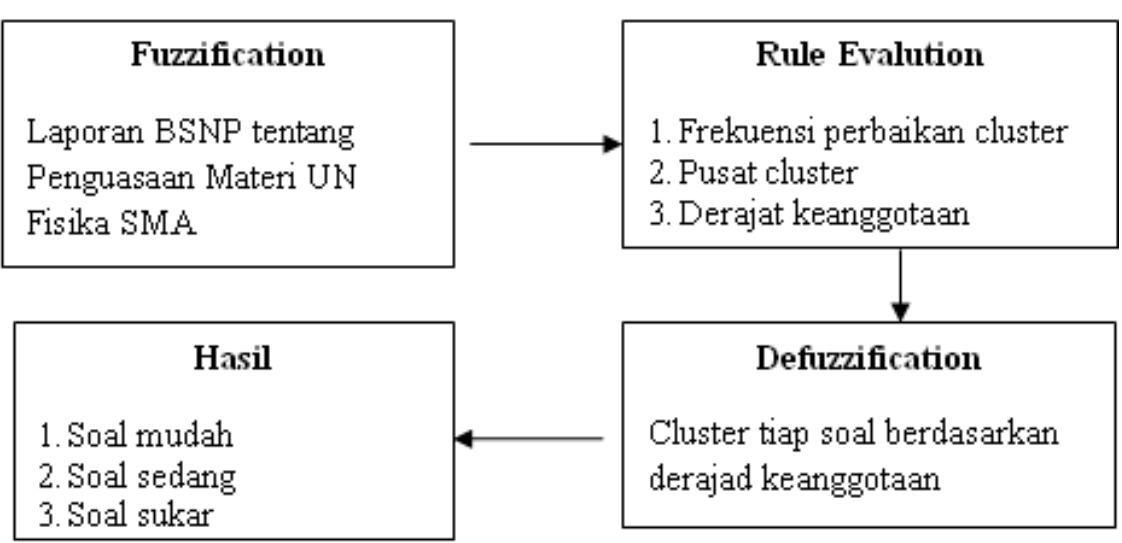

Gambar 2. Penerapan Fuzzy C-Mean Memetakan Soal UN Fisika SMA

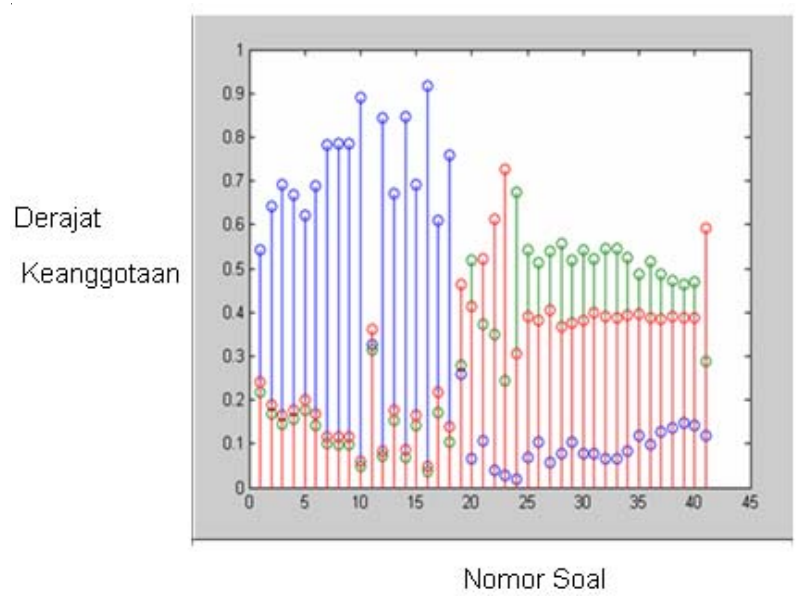

Gambar 3. Grafik Antara Derajad Keanggotaan Dengan Nomor Soal 
Untuk mengukur tingkat keberhasilan bahwa fuzzy c-mean dapat memetakan soal Ujian Nasional Fisika SMA adalah dengan melihat nilai try out Ujian Nasional Fisika yang dicapai kelompok control dan kelompok treatment . Untuk mempersiapkan Ujian Nasional, siswa kelas XII SMA N 7 Semarang harus mengikuti 4 kali Try Out yaitu 2 kali Try Out yang diselenggarakan Pemkot Kota Semarang dan 2 kali yang diselenggarakan SMA N 7 Semarang. Hasil pengujian t-Test nilai try out Ujian Nasional Fisika SMA dapat disajikan pada table berikut:
Dari data tersebut di atas dapat dianalisa bahwa kelompok kontrol memiliki rata-rata 75.60897436 dan kelompok treatment memiliki nilai rata-rata yang lebih bagus dari kelompok kontrol yaitu 86.88461538. Pada kelompok kontrol variance antara individu lebih besar dari kelompok treatment. Hal ini menunjukkan perbedaan kemampuan tingkat atas dan bawah pada kelompok control masih lebar. Sedang pada kelompok treatment mengecil, hal ini dapat dijelaskan setelah diberi tindakan maka perbedaan kemampuan kelompok atas dan bawah dapat dipersempit.

Tabel 6. Hasil Pengujian t-Test: Two-Sample

Assuming Equal Variances Try Out

Pada Kelompok Kontrol Kelompok dan Treatment

\begin{tabular}{|l|r|r|}
\hline & \multicolumn{1}{|c|}{ Variable 1} & \multicolumn{1}{|c|}{ Variable 2 } \\
\hline Mean & 75.60897436 & 86.88461538 \\
\hline Variance & 12.5782726 & 4.315283401 \\
\hline Observations & 39 & 39 \\
\hline Pooled Variance & 8.446778003 & \\
\hline $\begin{array}{l}\text { Hypothesized Mean } \\
\text { Difference }\end{array}$ & 0 & \\
\hline df & 76 & \\
\hline t Stat & -17.13219491 & \\
\hline P(T<=t) one-tail & $4.06137 \mathrm{E}-28$ & \\
\hline t Critical one-tail & 1.665151354 & \\
\hline P(T<=t) two-tail & $8.12275 \mathrm{E}-28$ & \\
\hline t Critical two-tail & 1.991672579 & \\
\hline
\end{tabular}

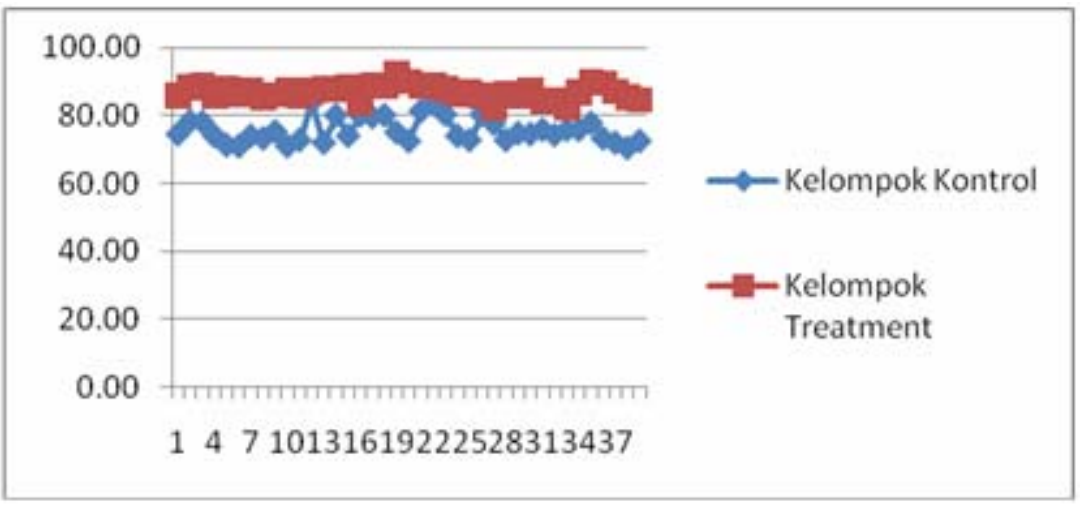

Gambar 5. Nilai Try Out pada kelompok Kontrol dan Treatment 
Terjadi perbedaan yang sangat signifikan pada kelompok kontrol dan kelompok treatment yaitu (-17.13219491). Dengan menggunakan game puzzle yang dibuat berdasarkan dari hasil metode fuzzy c-mean dapat meningkatkan prestasi siswa baik yang berkemampuan tinggi maupun rendah bahkan dapat mempersempit jurang perbedaan diantara mereka. Sehingga dapat diambil kesimpulan dengan metode fuzzy cmean berhasil memetakan soal UN Fisika SMA. Dengan melihat nilai $\mathrm{P}(\mathrm{T}<=\mathrm{t})$ two-tail lebih kecil dari 0,05 berarti Ho ditolak atau penerapan game efektif. Dari hasil tersebut dapat disimpulkan bahwa intelligent clustering system pada game puzzle dapat memetakan soal UN Fisika SMA.

\section{KESIMPULAN DAN SARAN}

\section{Kesimpulan}

Berdasarkan perancangan game, analisis dan hasil penelitian maka game puzzle berbasis fuzzy c-mean untuk memetakan soal Ujian Nasional dapat ditarik kesimpulan:

a. Terciptanya model pemetaan soal Ujian Nasional Fisika SMA dengan metode Fuzzy C-Mean untuk memudahkan proses desain evaluasi dalam Ujian Nasional dengan sebaran tingkat kesulitan yang proporsional.

b. Tersedianya latihan soal yang menyenangkan dan menantang dengan menggunakan game puzzle guna mempersiapkan siswa dalam Ujian Nasional Fisika SMA.

\section{Saran}

Dari hasil penelitian dan pembahasan terhadap game puzzle untuk memetakan soal Ujian Nasional Fisika yang dibuat dengan metode fuzzy c-mean maka saran yang diusulkan adalah sebagai berikut:

a. Game puzzle ini dapat dijadikan pendamping siswa kelas XII IImu Alam dalam mempersiap Ujian Nasional Fisika.

b. Game puzzle ini dapat dikembangkan dengan soal latihan yang lebih banyak. c. Game puzzle ini dapat dikembangkan ke mata pelajaran lain dalam rangka mempersiapkan siswa kelas XII menghadapi Ujian Nasional.

\section{DAFTAR PUSTAKA}

Adams, E. (2003). Break into The Game Industry How to Get A Job Making Video Game. California: Mc-Graw-Hill/Osborne.

Alizadeh, S. (2008). Using Data Mining for Learning and Clustering FCM. International Journal of Computational Intelligence , 108125.

Bethke, E. (2003). Game Development and Production. Texas: Wordware Publishing,Inc.

Bloom.s Taxonomi of Learning Domains. (10 Juni 2009). www.nwlink.com.

BSNP. (2008). Laporan Ujian Nasional Tahun 2008. Jakarta: Depdiknas, Badan Penelitian dan Pengembangan Pusat Penilaian Pendidikan.

Chuai-aree, S. (2001). Fuzzy C-Mean: A Statistical Feature Classification of Text and Image Segmentation Method. International Journal of Uncertainty, Fuzziness and KnowledgeBased Systems.vol 9 no 6, 661-671.

Davidson, B. (2006). Behavioral, Cognitive, and Humanistic Theories of Learning. www.associatedcontent.com/article/94979/ behavioral_cognitive_and_humanistic.html.

Dunn, J. (1993). A Fuzzy Relative of the ISODATA Process and Its Use in Detecting Compact Well-Separated Cluster. Journal of Cybernetics , 3:32-57.

EstivillCastro, V. (2006). Why so many Clustering Algorithms - A Position Paper. SIGKDD Eksploration, vol 4 , 1-65.

Galvao, J. (2000). Modeling Reality with Simulation Game for A Cooperative Learning. Proceedings of the 2000 Winter Simulation Conference, (pp. 1692-1699).

Gee, J. (2005). Good Video Game and Goog Learning. Madison Amerika Serikat: University of Wisconsin .

Kriegel, H. P. (2009). Clustering HightDimensional Data: A Survey on Subspace Clustering, Pattern-Based Clustering, and Correlation Clustering. ACM Transactions on Knowledge Discovery and Data, Vol 3 No 1 , $1-58$.

Liu, X. (2005). Using Fuzzy C-Mean and Fuzzy 
Integrals for Machinery Fault Diagnosis. In Proceedings International Conference on Condition , 1-10.

Pedersen, R. E. (2003). Game Design Foundations. Texas: Wordware Publishing Inc.

Permendiknas_no_77. (2008). tentang Ujian
Nasional Sekolah Menengah Atas/Madrasah Aliyah Tahun 2008-2009. Jakarta: Depdiknas. Srinivasan, V. (2008). Using Video Games to Enhance Learning in Digital. ACM 978-1-60558218-4, 196-199.

Srinivasan, V. (2008). Video Games to Enhance Learning in Digital. ACM 978-1-60558-218-4 , 196-199. 